\title{
The Analysis of the Relationship between the International Trade and the Environment Pollution
}

\author{
Zhongkai Shen \\ Department of Mathematics, Faculty of Science, National University of Singapore, Singapore \\ 119077, Singapore \\ zhongkaishen@gmail.com
}

\begin{abstract}
With the development of international trade, the environmental problems become more and more serious. This research firstly summarizes the environmental effects of international trade; based on this, the implicit pollution problem of international trade is analyzed. Then the international trade and environmental pollution status in China is analyzed to help promote the harmonious development of international trade and the environment protection.
\end{abstract}

Keywords: international trade; environment pollution; economic development.

\section{Introduction}

With the development of the economic globalization and trade liberalization, the global environment problems become more and more significant. The problems such as global warming, biodiversity decrease, forest decline, water pollution and land desertification are intensifying which makes people realized that the economic growth without the considering of environment and resources is unsustainable. As one of the most important economic activities, the international trade is closely connected with the natural environment since the moment it is generated. The liberalization of trade not only brings the high speed development of economy, but also accomplished with the worsening of ecological environment, and the international trade disputes related to environment also continually emerge. Apparently, the sustainable of international trade growth will lead to the continually extend of the need of the environment resources, while the supply of the environment resources is limited[1]. Then comes the contradiction between the liberalization of trade and the protection of environment[2]. So how to deal with the relationship between trade and environment to make them coordinated development and rising the living standard of people becomes a worldwide research subject.

\section{The environmental effect of international trade}

Since the 90 s of 20century, the relation between the international trade and environment has becomes one of hot topics in international academia. Whether the international trade is beneficial or harmful to the environment is the debate among economists. As the motivation of economic growth, on one hand, the international trade fueled the resource consumption and pollution emissions by boosting domestic product growth; while on the other hand, it also improved the level of real income which could help to solve environmental problems. In addition, the international trade can products more complex influence on the environment through the green trade wall ridge, environmental protection technology spillover, the increase of competition and the channels of pollution output and input. At present, the opinions of the environmental effect of international trade can be divided into three kinds: the harmful theory, the beneficial theory and the complex theory.

\subsection{The harmful theory}

The harmful theory thinks the international trade is harmful to the environment. Daly and Goodland questioned the relation between economic growth lead by foreign trade and environment protection, they think the trade growth neither can effectively promote the improvement of the social welfare, nor benefit to environmental protection. Especially to the developing country, the destructiveness of free trade is more prominent. Chichilnisky thinks under the established 
environment commodity prices, the developing countries which have incomplete property right mechanism always consume more environment resources than the developed counties[3]. Therefore, under the circumstances the property right has not been clearly defined, free trade can accelerate the destruction of the environment and resources in developing countries, thus further gives threats to the global environment.

\subsection{The beneficial theory}

The beneficial theory thinks the international trade can promote the environment. The economic-development-determination theory is proposed that the free trade not only make people have more resources and technologies to improve environment by enhance the level of income, but also conducive to the exchange of clean technology, products and services in international trade. Burniaux thinks that trade liberalization can reduce the distortion of the energy market, and reduce $\mathrm{CO} 2$ emissions in the worldwide through the analysis of a Computable General Equilibrium (CGE).

\subsection{The complex theory}

The complex theory not just consider unilaterally the beneficial or harmful of international trade to the environment. To account for the environmental effect of international trade, it classifies the effects of international trade on the environment into three aspects: the scale effect, the composition effect and the technique effect. The total effect depends on the size of those three effects including the positive and negative[4].

1)The scale effect can be interpreted as follows: under a certain technology level and trade structure, international trade would lead to the expand the scale of economic activities; while as the increase of productivities and the scale of economic, the use of natural resources and pollutant emissions will also increase. Another result of scale effect is the increase of income, according to the conclusion of the ECK, the increase of income is benefit to the environment when it is come to a turning point. The environmental effect of the increase of economic scale can be positive or negative, in the short term generally negative.

2) The composition effect comes from the specialized production. Under the circumstances of free trade, countries will focus on the production of products with comparative advantages. If a country's comparative advantage resources derive from the loose environmental regulations in this country, the international trade is harmful to environment. Under this conditions the other country would also specializing in the production of products with low environmental standards. Therefore, the composition effect of international trade need according to the specific circumstances.

3) The technique effect means the use of clean technology caused by the international trade. On one hand, it is the diffusion effect of technology which is foreign investors bring advanced technology to the host countries. On the other hand, with the improvement of the income, the needs of clean technology also increase, the host county will carry out stricter environmental standard to improve the environment. The technique effect usually leads to the improvement of a country's environment.

The total effect of international trade to the environment depends on the comparison of those three effects. The general equilibrium model usually used to analyze the size of the foreign trade to the effects of environment, structure and technology. The conclusion is often changes with the use of different samples and measurement methods in empirical analysis.

\section{The implicit pollution problem of international trade}

The implicit pollution problem in the international trade mainly includes trade implied carbon, $\mathrm{SO}_{2}$ and other implicit pollution, etc. The method mainly used in the measurement of the implicit pollution is the Input-output method which firstly applied in the national economic accounting. In the 70s of 20centry, as the problems of economic, energy and environment become more and more significant, many economists use input-output model in the energy economy and environmental economics to analyze the energy consumption, carbon emissions and environmental pollution problems[5]. The main research on the pollution embodied in trade can be divided into two aspects, the single regional input-output method and the multiple regional input-output method. The main measure object of both 
methods is certain industrial sector energy consumption and pollution content, then to calculate the total pollutant of import and export.

As to the single regional input-output method, only one input-output table is used in the calculation of a country's pollution content embodied in trade, especially in measuring the implied pollution on the imported products, the "import substitution" method is used. If the imported products produced in domestic, it will use their own technology, consume the domestic resources and discharge pollutants in their own country[6]. In this point of view, the pollutants contended in the import products is the reduction of domestic pollution.

As to the multiple regional input-output method, it uses the domestic input-output table to calculate the pollutant content in the export products, while uses the input-output table of the trading partners to calculate the pollutant content in the import products. Considering the difference of the level of technology and the usage of the energy among different countries, the result of multiple regional input-output method is more accurate and realistic, but the calculation is multifarious.

In addition to the single regional input-output method and the multiple regional input-output method, the Input-output table can also be divided into competitive (the import) input-output table and non-competition (the export) input-output tables. The competitive input-output doesn't distinguish the import investment and the domestic product investment in the middle investment part. While the non-competition input-output tables distinguishes the domestic intermediate input and the import product intermediate input. Apparently, those two have different precision, the competitive input-output calculation has double counting parts. Another worth noticed calculation method of pollution content embodied in trade is from the regional perspective. It researches a country's pollution content of different regions embodied in trade.

\section{The international trade and environmental pollution status in China}

Nowadays, the status of China's economic development is concurrent of the economic growth, the international trade expansion and the resource environment pressure. The development of Chinese international trade and the environment resource pressure accompanied by China's economic development are analyzed in this part.

\subsection{The rapid development of international trade in China}

The export scale of China is the largest in the world. China's import and export amounted to $\$ 3.8671$ trillion in 2012, 187 times higher than 1978. The increasing speed of china's international trade is 1.32 times of the GDP growth rate. As to the foreign trade dependence, the degree of dependence upon foreign trade up from $9 \%$ in 1978 to almost $50 \%$ in 2013 . As to the export structure, the manufactured goods account for more than $90 \%$ of total exports, the advantage sector of export gradually shifts from labor-intensive industries to capital-intensive industries. The energy-consuming, high pollution, resource-based exports account for a big share, such as mechanical and electrical,

textile, transportation, steel, chemical products all in the front row. After many years' development of international trade, china has become a "world factory".

\subsection{The growing environmental resources pressure in China}

The environmental resources pressure accompanied by China's economic development is increasing gradually. The expand of China's international trade scale no doubt brings a lot of energy consumption and pollution emissions. The total amount of various pollutant ranks top position in the world. In 1990-2012, the industrial waste gas emissions increased four times, industrial solid waste production amount increased almost 4 times. According to the national environmental pollution figures released by the European commission, several kinds of main atmospheric pollutants emissions growth rapidly in China, the SOX emissions is 20.24 million tons in 2000, while by 2009 that figure soared to 42.35 million. And in contrast, the main pollution gas emissions of China's major trading partner declines significantly during these years, such as America which the SOX emission declined $33 \%$. 
In the perspective of regional distribution, the development of foreign trade is very imbalance. The foreign trade scale of the eastern area is $90 \%$ of the total in China, while the trade scale of the central and western area is $5 \%$ each of the total scale. As to the pollution emissions, emissions in the east is higher than the central and western area, but the feature of pollution emissions in the east is not as significant as its trade development the reason of which is the lower pollution emission intensity of the eastern area. In the perspective of the industrial sector, with the expanding of export trade, the pollutant emissions of industrial sector also growing rapidly, the growth of those two have a certain correlation

\section{Conclusion}

As the discussion of the relationship between the development of the economic and international trade and the environment pollution becomes the hot topic, it is significant to figure out the environmental effect of international trade. It is very necessary and urgent to change the growth mode and optimize the structure of international trade to help improve the environment development, and help adjust the trade policy guidance from the perspective of environmental protection to promote the harmonious development of foreign trade and the environment.

\section{References}

[1] Beladi, H. and R. Oladi, Does trade liberalization increase global pollution? Resource \& Energy Economics, 2011. 33(1): p. 172-178.

[2] [Antweiler, W. and M.S. Taylor, Is Free Trade Good for the Environment? Nber Working Papers, 1998. 91(4): p. 877-908.

[3] Chichilnisky, G., North-South trade and the global environment. American Economic Review, 1994. 84(4): p. págs. 851-874.

[4] Burniaux, J.M., and Green: a multi-sector, multi-region dynamic general equilibrium model for quantifying the costs of curbing CO 2 emissions: a technical manual. 1992.

[5] Dean, J.M. and M.E. Lovely, Trade growth, production fragmentation, and China's environment. Social Science Electronic Publishing, 2010. In press.

[6] Kahrl, F. and D. Roland-Holst, Energy and exports in China. China Economic Review, 2008. 19(4): p. 649-658. 